\title{
The (im) possibilities of the common: an opinion on the erasing of differences in brazilian curriculum reform
}

\begin{abstract}
This paper brings an opinion on curricular policies in Brazil. We hope it will enrich international debates on education through a discussion of the salient issues preoccupying curriculum scholars in Brazil as the curriculum reform that menaces the democratic parameters of education. Using mainly the theoretical bases established by Hannah Arendt and William F. Pinar, we begin with an analysis of the socio historical context of and policies reshaping basic public education in Brazil. Thus, following Arendt, we look at the present, when public and democratic schools are being threatened by a conservative neoliberal tsunami. ${ }^{1}$ We advocate that the unified curriculum is an (Im) possibility in terms of the creation of democratic historicities, subjectivities - and community. Common Core is uniformization - in other words, the erasing of difference that hinders the achieving of democracy and social justice.
\end{abstract}

Volume 2 Issue I - 2018

\author{
Maria Luiza Süssekind, Manuela Moreira \\ Porto, Matheus Saldanha do Amaral Reis \\ Federal University of Rio de Janeiro, Brazil
}

Correspondence: Maria Luiza Süssekind, Federal University of Rio de Janeiro State Av pasteur 458 Urca Rio de Janeiro, Brazil, Tel 5521995221516,Email luli55।@hotmail.com

Received: October 24, 2017 | Published: January 19, 2018

\section{Curriculum reform in brazil}

Recently approved by the Brazilian Senate, following the unfortunate success of the National Curriculum Common Core's trends $^{1}$, the High School Curriculum Reform was the key event that motivated this manuscript and the aim to look to our peers for knowledge exchange and political support. Since we are congregate her as history teachers, we are dismayed at the total withdrawal of this discipline from high school curricula in Brazil. Not only history, but all other segments of the social sciences have lost importance in the new unified curricula in Brazil Following Arendt. ${ }^{2}$ we contend that the growing loss of tradition and forgetting about the past is one of the greatest problems of contemporary society, and often the main reason for deep global crises. Considering natality ${ }^{2}$ to be the essence of education, the author affirms the necessity of respecting history and of maintaining the common world ${ }^{3}$. In this direction, historicity is composed of intense negotiation, a negotiation that involves human relations and the various political interests that determine the rhythms of each community. We therefore underscore the importance of teaching history within the basic school curriculum, exalting its political and social importance both in the Brazilian and in the world context, not as a vehicle distributing the meanings of democracy in a way common to all, but as spacetime, ${ }^{3}$ in which the rewriting of stories and living historicities is what exists and creates the common, as a community of differences. ${ }^{4}$ The High School Curriculum Reform erases all possible relationships and wealth of knowledge that legitimizes the field of history, as a political and community building praxis. Following Arendt, we look at the present, when public and democratic schools are being threatened by a conservative neoliberal tsunami ${ }^{1}$ that commercializes education, censures free thinking, and demonizes teachers for not achieving efficiency and uniform results, per Pinar. ${ }^{5}$ Agreeing with Pinar we defend that the curriculum is a compacted conversation among all the society bringing historicities and subjectivities, layering narratives, weaving nets of knowledge and solidarity ${ }^{3}$ and disrupting the fantasies of harmony with dissensus, diversity, difference, blindness and un-blindness movements. ${ }^{4}$

${ }^{1}$ The National Curriculum Common Core, known in Brazil as Base Nacional Comum Curricular (BNCC), it is a 2016 document that seeks to impose a common curriculum at all levels of education. Idealized as a miraculous document, the BNCC categorizes knowledge and articulates lists of contents considered as essential learning results in the education of students and teachers. The National Curriculum Common Core project has gone through four distinct versions (only three of them official), and the progressive loss in the role of history and the human sciences disciplines was remarkable. In contrast, it is important to realize how the exact sciences and their marketing methods gain strength in the curricular discussions present in the latest versions of BNCC. Regardless of adopting left political stances or not, it is quite visible how the curriculum has become a weapon of mass transformation (Oliveira, Süssekind, 2015).

${ }^{2}$ For Arendt, "natality" has a direct connection to the world, one built by the ancients, that must continue to be respected with its traditions kept and the past assured. Only then can innovations and continuities follow in a natural way. We can approach this idea to the philosophy of difference by Derrida (2014) where heritage is the unfolding and weaving of solidarity, justice and love.

${ }^{3}$ The world in question-the "common world," where the relations and characteristics of society express themselves-is the world of men. These men (and women, and LGBTTQ) as generations go by, ensure the survival of customs and characteristics that are fundamental to political and social existence.

The architects of the Brazilian Common Core (BNCC) and those involved with private investments in the Brazilian education area, allied with their arsenals of resolutions, exalt a patriotic admiration by the political and educational parameters adopted in North America. These patriotic analyses fail to present the true contexts and the countless problems that exist in the relationship between schoolsociety-democracy in the most diverse regions in United States. Hannah Arendt ${ }^{6}$ on numerous occasions describes with discomfort the practices of blindness and sociopolitical relations directed towards basic education. Most recently, Todd Alan Price ${ }^{7,8}$ works on the idea of the common curriculum to question the false notion of equality and democracy that involves the educational parameters in the United States of America. Many other important authors bravely struggled for ages against the implementation of curricular centralization 
policies in the most diverse American state, so in which context do the "education specialists" "here in Brazil live to ignore the growing theoretical and practical discussions about the curriculum on a global scale? Business and private investment interests in education are aligned with the intensification of control strategies across the globe. Such intensification is felt in the Brazilian curricular field in the form of employability, citizenship or, simply, good results in international tests. ${ }^{9}$ All these points disregard the differences and plan results that are impossible to achieve in a real and democratic society.

${ }^{4}$ Apparently concerned with educational systems, corporate media play a prominent role in promoting "specialists" who silence teachers, exclude them from curricular debates, and criminalize them publicly. The (in)competencies of teachers occupy the full attention of the debates while students are still treated as disinterested and incapable. The emergence of the "education specialists" is directly connected with the conservative neoliberal tsunami (Süssekind, 2014) where the quality of teaching means results in standardized tests promoted by business instances. As a result of this policy, we identify the growth of the analyzes of the Brazilian educational system based on numbers that make the practicing / thinking subjects invisible (Oliveira, 2012).

\section{The (im)possibilities of the common}

Acclaimed as a good recipe by most of those who call themselves specialists in education, the American Common Core has become a major political and social goal in Brazil in the last 12 years. The intense search for results in international tests, as well as the impracticable discourse on the education for citizenship, end up generating great questions when it comes to the school curriculum. Such aspect is silenced by the impositions of oppressive policies promoted right after the coup ${ }^{5}$ Arendt $^{2}$ points to the devastating effects of the imposition of education policies, even when they are supposedly a pro diversity and democratic regulation, within schools in the USA. Considering the concept of difference Derrida ${ }^{10}$ as an ontological condition and also the diversity of origins, cultures and nationalities within the United States of America, the policies that claim for unified curriculum values monocultural tendencies and lead to an erasure of differences, the production of non-existence is closely linked to the political and social processes of building invisibility. ${ }^{4}$ The Common Core makes this quite clear in its general lines of understanding, where the production of failure gains more prominence than the understanding of the differences. We cannot forget that the denial of difference is one of the strongest strategies of the justified production of inequality, and the mainstream of the linear, epistemicidal capitalistic teleological worldview.

${ }^{5}$ Following the considerations made by Jessé Souza (2016, p.23) we understand the coup as a legal-political-media-legislativejuridical mechanism that served to the political and financial interests of a small layer of society that holds capital and power. According to Souza, the removal of President Dilma Rousseff is not different from the numerous democratic coups and disruptions historically registered within the social and political sphere in Brazil.

Understanding the curriculum as a complicated conversation ${ }^{5}$ we aim to defend that curriculum is an everyday life creation ${ }^{11}$ that lies with the differences, the complexity of human networks, ${ }^{12}$ and the epistemological diversity of the world ${ }^{13}$ Rather than simply trying to exalt the different groups and practices within the school setting, we need to take away from silence and forgetfulness the ontological and human meaning of difference. Throughout conversations ${ }^{14}$ and narratives we may built knowledges that can mean something for all of us, definitely disregarding the possibility of a unique knowledge shaped from any a priori defined common interests. Our work is guided by the idea of school space as a rich space of collaboration, ${ }^{5}$ with multiple ways of knowing and interests. The power of the collective ${ }^{3}$ within the practice and the curricular elaborations must be placed on a theoretical place of irrefutable importance. ${ }^{1-15}$ The culture of the bad teacher is another effect of the reductive procedures built and intensified by the unified curricula. Just as students and learning, teachers and teaching are also made also invisible and dehumanized. ${ }^{1}$ Teachers increasingly have fewer opportunities of practicing curricula as complicated conversations while classrooms cease to be a space for negotiation and become calculated spaces of oppression and imposition of rules and values and reified knowledge testing. The unification identifies difference and diversity as deviations, deficiencies, disabilities, and maintains general and standardized assessments as an important element in constructing justifications for school failure. ${ }^{16}$ Like unified teaching materials produced by education specialists - some whom have never set foot in a classroom - teaching methodologies are also adjusted according to the conservative hegemonic interests of exclusion. Market interests. The real question that guides most of the problems we currently face with the unified curricula is that there is a shortage of professionals who are genuinely involved in education in positions related to educational policies. Education, especially in the last decades, has become a large global market where students are products and their results generate resources for the school institutions and governments involved. There is no humanity or historicity involved in knowledge creation in this viewpoint.

At last but not least, we have been emphasizing the conceptual impossibility of a prescribed curriculum being able to build itself as a space for translations, re-readings and profound modifications within the most different ways to know of the world, as they largely announce. ${ }^{4}$ The constant negotiation of meanings and policies makes curricula sustained by immutable rules, as the BNCC, simply not possible within everyday school life as we understand it epistemologically and politically. Rules and principles will always be disputed and this is an essential part of all policies, from the most complex to the most simple and mediocre, from the most democratically builded to the authoritarian ones. With the foresight of a historian, we always seek the $\operatorname{traces}^{17}$ of a tradition ${ }^{2}$ that can never be abandoned, for it is this story that truly demonstrates the colors and multiplicity that exists within the school classes and within the complicated conversation that is curriculum.

\section{The erasing of differences}

As in Brazil, the United States of America has a continental territorial dimension, sheltering latent knowledges and peculiarities from region to region, thus highlighting the gigantic difference of understanding and practices that maintain the functioning of the world itself. To ignore differences is to ignore the tradition forged by the longest generations, and this directly attacks our identities and our histories. ${ }^{18}$ We advocate that the unified curricula, the common core, is an (im) possibility in terms of the creation of historicities, subjectivities-and community, in Arendt's sense. This Common Core is hegemony and uniformization-in other words, the erasing of difference, which does not help, but rather hinders the achieving of democracy and social justice. Beyond that is also an ontological issue for those who recognize the human as a permanent creation of difference. ${ }^{9}$ 
The struggle for rights and the growth of social movements in the United States positively influence the social activism movements on a global scale, as a worldwide influencer, American events sensitize and boost a large part of groups of other nations. Unfortunately, the social conquests of many, generate the hatred of groups that hide in the shadows of history, the differences arouse the fury of hegemonically dominating groups, and the loss of their spaces of coercion causes many ideologies buried in the past to awaken with all force. At the beginning of our work, we would never imagine having to work with the idea of Nazism. For all its tragic dimensions in the recent past, it is hard to believe how such movements are able to gain momentum at a time of so many social achievements in the United States of America and in Brazil. For Arendt ${ }^{2}$ this is not surprising, since the society is much more complex than it actually seems, especially the American where its consolidations are shaped from the difference and conflict.

Arendt ${ }^{19}$ considers that all movements and policies that have the purpose of erasing, in some way, the identities and knowledges of any community, are events of non-history. The total break with tradition and the functioning of the common world, for the author, is one of the most delicate moments that can be predicted for the general health of a society; in particular, the non-manifestation of repudiation by a large number of US officials, especially US President Donald Trump, directly means support for Nazi white supremacist practices, the white silence is the white consent. The neoliberal conservative tsunami is increasingly reactive, its magnitude adjusted, as the excluded are able to occupy new spaces of their right in the society, the acceptance of Nazi ideology is proof that there are no limits to immorality. As we have seen with class referenced hates, misogyny narratives and political persecutions in the last few years in Brazil. ${ }^{20}$

Even without the face of Nazism, as is the case with recent movements in the United States of America, some barbarian events in Brazil also leave us without sleep. The homosexuality at the time of this writing is being (again) discussed as a disease in Brazilian journalistic vehicles. Medical psychologists and psychiatrists are offering gay cure for their patients, backed by a government injunction that allows for sexual reversal therapies in the name of "full scientific freedom". After so many achievements in various sectors of politics and society, it is hard to believe how uncertainties take over our future, twenty-seven years ago, the World Health Organization stopped treating homosexuality as an illness, but the number of gay cure supporters that still in Brazil today is scary. As in a battle for human rights that we thought were conquered, we understand why Santos ${ }^{12}$ argue so furiously that civil and human rights are narratives about rights that use many social actors as objects and not subjects of those rights. Working with these events helps us to identify some of the problems present in societies as unequal as the American and the Brazilian, but prejudices and erasures are constantly present in our daily lives in more subtle and devastating ways. Small practices often achieve tragic results, always considering that the denial of the right to difference is always made up of violent actions. ${ }^{15}$

\section{Final considerations}

Having set forth the situation of consolidation via the coup d'état ${ }^{19}$ and the the politics of erasing difference in the Brazilian context, we highlight how this is part of the global conservative tsunami ${ }^{4}$ that has led also to the recent American political events around the issue of white supremacy under Trump's presidency. Arendt affirms that "[a] crisis becomes a disaster only when we respond to it with preformed judgments, that is, with prejudices", ${ }^{2}$ which underlines how difficult it is to deal with the differences and the hybridity of the American continent communities. We live in a prejudiced society, and this becomes very clear within the educational practices of everyday life. Even though American issues do not seriously disturb socialpolitical relations in Brazil, different realities as well as multiculturalities pose a great danger to hegemonic knowledge and colonial perseverant values and practices. The adoption of unified curricula seeks to silence the different, isolating cultures and peripheral acquirements even more. Its epistemicidal ${ }^{12}$ because it's the reinforcement of the nets of knowledge that supports colonialism, patriarchalism and capitalism. Above all, school curriculum should acknowledge the wealth we can draw from diference, including what has been excluded and discriminated against in society. ${ }^{21}$ Considering that in addition to pluricultural Brazilian and North American society are extremely unequal, we always need to combat the common. Joints that try to standardize our ways of being, acting and thinking are not compatible with human nature; these practices erase the differences and unbalance the pillars that sustain the common world. Equality is the right of difference is our statement as curriculum scholars. The conservative neoliberal tsunami throws us into the limbo of social facts, ${ }^{22}$ where we are nothing more than instruments of oppression and abuse. For these reasons, the work with tradition ${ }^{2}$ is necessary to be highlighted as a not yet for those who stand up against epistemicidal projects of society since only it is capable of emphasizing the difficulties and the real articulations present in the complex social composition in which we live. In moments of latent political crisis that menaces the democracy institutions in Brazil the struggle for rights and identities is the only possible way to think and defend difference as a curricular thinking-practice. ${ }^{23}$

\section{Acknowledgments}

None.

\section{Conflict of interest}

The author declares no conflict of interest.

\section{References}

1. Süssekind ML. Taking advantage of the paradigmatic crisis: Brazilian Everyday Life Studies as a new epistemological approach to the understanding of teacher's work. Citizenship, Social and Economics Education. 2014;13(3):199-210.

2. Arendt, Hannah. The crisis in education. In Between past and future: Six exercises in political thought. 1961:173-196.

3. Alves Nilda. Decifrando o pergaminho - o cotidiano das escolas nas lógicas das redes cotidianas. Deciphering the parchment - the everyday life within schools in the logics of everyday life networks. cotidiano das escolas - sobre redes de saberes. Rio de Janeir, Brazil; 2001. p. 1-15.

4. Süssekind ML. As (im)possibilidades de uma Base Comum Nacional. Revista E-Curriculum. 2014;12(3):1512-1529.

5. Pinar W F. What is curriculum theory. 2nd ed. India: T\&F Routledge; 2012. p. 1-296.

6. Arend Hannah. The human condition. 2nd ed. USA: American National Standard for Information Sciences; 1958. p. 1-329.

7. Price TA. The Real Common Core: Education for the few. 2014

8. Price TA. Comum para quem. Revista e-Curriculum. 2014;12(3):1614 1633.

9. Macedo Elizabeth. Base nacional curricular comum: a falsa oposição entre conhecimento para fazer algo e conhecimento em si. Educ Rev. 2016;32(2):45-68. 
10. Derrida J. A escritura e a diferença. 2014;17(2):38-60.

11. Oliveira IB. O Currículo como criação cotidiana. Currículo sem Fronteiras. 2012;13(3):375-391.

12. Manhães, Luiz C.S. Redes e formação de educadores. Networks and formation of educators. Recebido em janeiro de Cad. CEDES 2004;29(77):1-12.

13. Santos. Para além do pensamento abissal. [Beyond abyssal thinking] São Paulo Cortez. 2010;79:31-83.

14. De Certeau Michel. A invenção do cotidiano: 1. As artes de fazer. Di logo Educ Curiti. 1994;7(22):115-128.

15. Pinar WF. Curriculum studies in Brazil: intellectual histories, present circumstances. Palgrave Macmillan, USA; 2011. p. 1-254.

16. Esteban Maria Teresa. A negação do direito à diferença no cotidiano escolar. The denial of the right to difference in everyday school life Avaliação Campinas Sorocaba São Paulo. 2014;19(2):1-24.

17. Ginzburg C. Mitos, Emblemas e Sinais. Morfologia e História. Myths, Emblems and Signs. Morphology and History. São Paulo Cia das Letras. 1989:7-221.
18. Arendt Hannah. Reflections on Little Rock Dissent. 1959;6(1):45-56.

19. Arendt Hannah. Truth and politics. In Between past and future: Eight exercises in political thought. USA: Viking Press; 1967. p. 227-264.

20. Souza Jessé. A Radiografia do Golpe: entenda como e porque você foi enganado. [The Radiograph of the Coup: Understand how and why you were deceived] Rio de Janeiro LeYa. 2016:1-3.

21. Agamben Giorgio. The coming community Trans. Michael Hardt. Minneapolis: University of Minnesota Press, Minneapolis. Originally published as La communità che viene Einaudi. 1993:1-117.

22. Durkheim Émile. The Rules of Sociological Method and Selected Texts on Sociology and its Method. USA: Free Press; 1982. p. 50-59.

23. Oliveira IB, Süssekind ML. From the Critical Theories to the Critique of the Theories: dialogues between social thought and its appropriations through educational debates in Brazil. International Critical Pedagogy Reader. UK: Routledge; 2015. p. 1-350. 